\title{
Estimating spatial pattern of hyporheic water exchange in slack water pool
}

\author{
SONG Jinxi ${ }^{1,2}$, CHENG Dandong ${ }^{1,3}$, ZHANG Junlong ${ }^{2,4}$, ZHANG Yongqiang ${ }^{5}$, \\ LONG Yongqing ${ }^{2}$, ZHANG Yan ${ }^{2}$, SHEN Weibo ${ }^{1}$ \\ 1. State Key Laboratory of Soil Erosion and Dryland Farming on the Loess Plateau, Institute of Soil and Water \\ Conservation, CAS \& MWR, Yangling 712100, Shaanxi, China; \\ 2. Shaanxi Key Laboratory of Earth Surface System and Environmental Carrying Capacity, College of Urban \\ and Environmental Sciences, Northwest University, Xi'an 710127, China; \\ 3. University of Chinese Academy of Sciences, Beijing 100049, China; \\ 4. College of Geography and Environment, Shandong Normal University, Jinan 250358, China; \\ 5. CSIRO Land and Water, GPO Box 1666, ACTON 2601, Canberra, Australia
}

\begin{abstract}
Hyporheic zone ( $\mathrm{HZ})$ influences hydraulic and biogeochemical processes in and alongside streams, therefore, investigating the controlling geographic factors is beneficial for understanding the hydrological processes in HZ. Slack water pool (SWP) is an essential micro-topographic structure that has an impact on surface water and groundwater interactions in the $\mathrm{HZ}$ during and after high flows. However, only a few studies investigate $\mathrm{HZ}$ surface water and groundwater exchange in the SWP. This study used the thermal method to estimate the $\mathrm{HZ}$ water exchange in the SWP in a segment of the Weihe River in China during the winter season. The findings show that on the flow-direction parallel to the stream, river recharge dominates the $\mathrm{HZ}$ water exchange, while on the opposing flow-direction bank groundwater discharge dominates the water exchange. The water exchange in the opposing flow-direction bank is about 1.6 times of that in the flow-direction bank. The $\mathrm{HZ}$ water exchange is not only controlled by flow velocity but also the location and shape of the SWP. Great water exchange amount corresponds to the shape with more deformation. The maximum water exchange within the SWP is close to the river bank where the edge is relatively high. This study provides some guidelines for water resources management during flooding events.
\end{abstract}

Keywords: hyporheic water exchange; thermal method; discharge; recharge; surface water-groundwater interactions

\section{Introduction}

Hyporheic zone (HZ), the saturated zone alongside and beneath the streambed where surface and groundwater interactions take place (Marzadri et al., 2014), is a key component influ-

Received: 2018-02-14 Accepted: 2018-06-10

Foundation: National Natural Science Foundation of China, No.51679200; No.51379175; Program for Key Science and Technology Innovation Team in Shaanxi Province, No.2014KCT-27; The Hundred Talents Program of the Chinese Academy of Sciences, No.A315021406; Specialized Research Fund for the Doctoral Program of Higher Education, No.20136101110001

Author: Song Jinxi (1971-), Professor, E-mail: jinxisong@nwu.edu.cn 
encing hydraulic and biogeochemical processes (Fischer et al., 2005; Korbel and Hose, 2015; Stegen et al., 2018; Wang et al., 2018). Its function may have a significant effect on stream hydrological processes, water quality (Westhoff et al., 2011), and river ecosystem (Mendoza-Lera and Datry, 2017). Various factors can lead to the transport of water and flux through HZ (e.g., hydraulic conductivity (Trauth and Fleckenstein, 2017)). Micro-topography as one of an important factors (Frei et al., 2010; Zhang et al., 2016; Gualtieri et al., 2017; Ianniruberto et al., 2017), controlling fine-scale variability in hydraulic heads, is fundamental for the HZ water exchange at the habitat scale ( $\sim 1$ to $10 \mathrm{~m})$ (Naiman and Latterell, 2005). The water exchange in the $\mathrm{HZ}$ is still less understood owing to the disparate environmental conditions (e.g., sediments structure and topography), it is a challenge to elucidate the effects of particular micro-topographic features on the interactions between surface water and groundwater (Boano et al., 2006; Tonina and Buffington, 2007).

$\mathrm{HZ}$ water exchange under various micro-topographic features has been investigated in many studies (e.g., hollows and hummocks (Frei et al., 2010), bedding orientation (Cheng et al., 2013), hillslope (Boulton et al., 2010; Dochartaigh et al., 2012), riffles (Storey et al., 2003), stream curvature (Cardenas et al., 2004) and confluence (Gualtieri et al., 2017; Ianniruberto et al., 2017)). Other authors publish the related findings at micro-topographies settings (see Table 1). The micro-topography is a vital driver leading to the spatial changes of hydrological processes in HZ. It affected the subsurface water exchange and nutrient transports (Frei et al., 2010; Caruso et al., 2016; Song et al., 2017), therefore, in turn, it has potential implications for the ecological habits (Stubbington, 2012). Moreover, there are high demands to understand the $\mathrm{HZ}$ water exchange in a specific micro-topography.

Table 1 Properties for some micro-topographies

\begin{tabular}{|c|c|c|c|c|c|}
\hline $\begin{array}{c}\text { Micro-topographic } \\
\text { feature } \\
\end{array}$ & $\begin{array}{c}\text { Location in the } \\
\text { HZ }\end{array}$ & $\begin{array}{c}\text { HZ exchange } \\
\text { patterns }\end{array}$ & Influencing factors & Analysis method & Reference \\
\hline $\begin{array}{l}\text { Hollows and } \\
\text { hummocks }\end{array}$ & Floodplain & Frequent shifts & Runoff generation & $\begin{array}{l}\text { Virtual modeling } \\
\text { experiment }\end{array}$ & Frei et al. (2010) \\
\hline Bank hillslope & $\begin{array}{l}\text { Stream mar- } \\
\text { gin/floodplain }\end{array}$ & $\begin{array}{l}\text { Mainly dis- } \\
\text { charge }\end{array}$ & $\begin{array}{l}\text { Groundwater head, } \\
\text { soil permeability }\end{array}$ & $\begin{array}{l}\text { 3D geological } \\
\text { model }\end{array}$ & $\begin{array}{l}\text { Dochartaigh et al. } \\
\text { (2012) }\end{array}$ \\
\hline Pool-riffle & Riverbed & $\begin{array}{l}\text { Complex in- } \\
\text { teractions }\end{array}$ & $\begin{array}{l}\text { Bedform-induced } \\
\text { advection }\end{array}$ & $\begin{array}{l}\text { Laboratory ex- } \\
\text { periments and } \\
\text { pumping ex- } \\
\text { change model }\end{array}$ & $\begin{array}{l}\text { Tonina and Buffington } \\
(2007)\end{array}$ \\
\hline Riffle & Riverbed & Mixed $^{a}$ & $\begin{array}{l}\text { Hydraulic conduc- } \\
\text { tivity, groundwater } \\
\text { flux }\end{array}$ & $\begin{array}{l}\text { MODFLOW, } \\
\text { Numerical } \\
\text { heat-transport } \\
\text { model }\end{array}$ & $\begin{array}{l}\text { Storey et al. (2003); } \\
\text { Vogt et al. (2012) }\end{array}$ \\
\hline Dunes and eddies & Riverbed & $\begin{array}{l}\text { Differ in } \\
\text { depths }\end{array}$ & Pressure gradient & $\begin{array}{l}\text { Governing equa- } \\
\text { tions for fluid, } \\
\text { tracer method }\end{array}$ & $\begin{array}{l}\text { Fox et al. (2014); Chen } \\
\text { et al. (2015) }\end{array}$ \\
\hline Slack water pools & $\begin{array}{l}\text { Stream mar- } \\
\text { gin/floodplain }\end{array}$ & $\begin{array}{l}\text { Complex in- } \\
\text { teraction }\end{array}$ & $\begin{array}{l}\text { Flow velocity and } \\
\text { shape }\end{array}$ & Thermal method & Present study \\
\hline
\end{tabular}

${ }^{a}$ Mixed, means the $\mathrm{HZ}$ water exchange in this condition is an interaction with spatial and diurnal variations at small scale.

Slack water pool (SWP) is a pool-like depression along the stream margin and on the floodplain that contains water only during high flow or after flood recede, it may hold water for only a few days or weeks (Dunster, 2011). It is characterized by low flow velocity and relatively static water level. Though SWP is a common feature in a river system, HZ water 
exchange within the SWP is poorly understood, and few studies have been reported (Kasahara and Wondzell, 2003; Cardenas et al., 2004). The HZ water exchange within the SWP is strongly influenced both by groundwater and streamflow due to close hydraulic connection with rivers, unlike other micro-topographies which are entirely nested in the riverbed.

Table 1 summarizes studies of micro-topographic effects on the $\mathrm{HZ}$ water exchange, influencing landscape elements and methods employed in their investigation. There are several methods (e.g., hydraulic conductivity (Chen et al., 2013), hydraulic gradient (Baxter et al., 2003), seepage meter (Isiorho and Meyer, 1999), isotope tracer (Darracq et al., 2009), numerical simulation (Lautz and Siegel, 2006) and heat tracers (Kalbus et al., 2006)) implemented to calculate the water exchange in the HZ. Among those methodologies, thermal method is widely used since point measurements of streambed temperatures can be efficiently detectable and obtained (Somogyvári et al., 2016), and analytical/numerical methods used in their interpretation can provide reliable exchange estimates when measurements were performed under the appropriate conditions (Schmidt et al., 2007).

This study uses the one-dimensional method to investigate the $\mathrm{HZ}$ water exchange in a relatively small ( $<20 \mathrm{~m}$ length) SWP in the Weihe River (Figures 1 and 2), a major tributary of the Yellow River, and to address the primary mechanism of water exchange between the stream and groundwater in the SWP.

\section{Field site and measurements}

The test site is located on the segment of the Weihe River in Meixian, the upstream where the river enters Shaanxi Province (Figure 1). The Weihe River is the first tributary of the Yellow River, which originates from Gansu Province, China. It runs across $818 \mathrm{~km}$ and joins the Yellow River in the city of Tongguan. The length in Shaanxi Province accounts for about $61 \%$ of the total length of the river. The annual rainfall is from 558 to $750 \mathrm{~mm}$ and with a mean approximately $610 \mathrm{~mm}$. The drainage area, annual flow flux and annual sediment discharge of the river account for $17.9 \%, 16.9 \%$ and $2.5 \%$ of the total amount of the Yellow River Basin, respectively (Li et al., 2013).

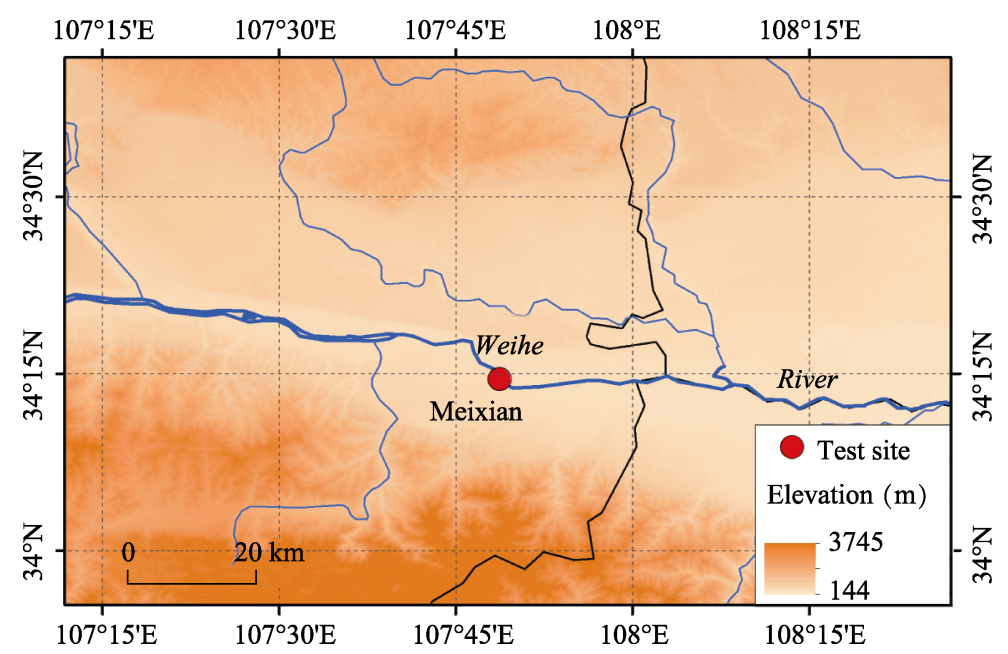

Figure 1 Map showing the location of the study area and the test site 
The river has natural channel morphology with a width of $34 \mathrm{~m}$ and its course travels in a southwest direction in this reach, the SWP is situated in the southern river bank. The SWP is composed of three parts, the static part, the path belt and the main river channel. The streambed deposits consist primarily of loose, fluvial deposited, and gravel. The loose sediment and sand are distributed on the upper layer in the vicinity of the bank, and the gravel extensively occupies on this section of streambed. In the static part of the SWP, the sedimentary structure is mainly composed of the loose and coarse sand. The bank of the static part consists of fine to very fine sands with occasional silty areas. Fine sand extends from the surface to a depth of about $0.5 \mathrm{~m}$ where we found a discrete layer of sand and gravel in the bank of the river. The streambeds are relatively uniform in the upper layer of the sediment.

The experiment was carried out on 25 Jan 2015, from 11 am to $15 \mathrm{pm}$. In monitoring period, the air and water temperatures were $4.58 \pm 1.70(\mathrm{SD})$ and $5.03 \pm 0.74(\mathrm{SD}){ }^{\circ} \mathrm{C}$, respectively. The thermistor with the multiple depths has been used to record the sediment temperatures at the testing points (Figure 2). Temperature sensor (Heraeus, pt 100) has been installed at $0.00 \mathrm{~m}, 0.10 \mathrm{~m}, 0.20 \mathrm{~m}$, $0.30 \mathrm{~m}, 0.45 \mathrm{~m}, 0.60 \mathrm{~m}$ and $0.80 \mathrm{~m}$, respectively. The measuring range of the sensor is from $-50^{\circ} \mathrm{C}$ to $200^{\circ} \mathrm{C}$.

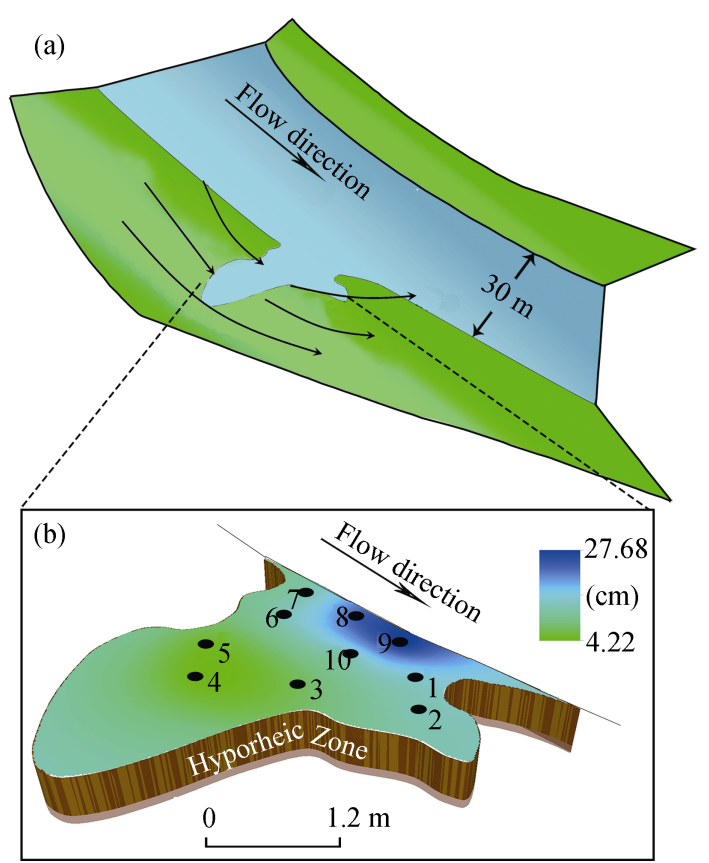

Figure 2 Map showing the measurements of the sediment temperature and water depth. (a. Position of the slack water pool; b. Description of water depth at the testing site

\section{Methods}

\subsection{Thermal method}

The one-dimensional method is a simple analytical solution that can provide an inexpensive, efficient approach to obtain accurate point estimates of $\mathrm{HZ}$ water exchange using streambed temperatures (Anibas et al., 2009; Irvine et al., 2015). The assumption of the HZ water exchange in SWP is just vertical directions (upward or downward), the water exchange rate can be expressed as following (Suzuki, 1960):

$$
\frac{K}{\rho c} \frac{\partial^{2} T(z)}{\partial z^{2}}-\frac{Q_{v} \rho_{0} c_{0}}{\rho c} \frac{d T(z)}{d z}=\frac{\partial T(z)}{\partial t}
$$

where $T(z)$ is the temperature $\left({ }^{\circ} \mathrm{C}\right)$ of the streambed sediments at $z$ depth; $K$ is the heat conductivity $\left(\mathrm{J} \mathrm{s}^{-1} \mathrm{~m}^{-1} \mathrm{~K}^{-1}\right) ; \rho c$ is the volumetric heat capacity of saturated streambed system $\left(\mathrm{J} \mathrm{m}^{-3} \mathrm{~K}^{-1}\right) ; \rho_{0} c_{0}$ is volumetric heat capacity of the water $\left(\mathrm{J} \mathrm{m}^{-3} \mathrm{~K}^{-1}\right)$; and $Q_{v}(\mathrm{~mm} / \mathrm{d})$ is the vertical water exchange through a unit area. 
When in thermal steady state conditions, the right hand of Equation (1) tends to 0 and can be arranged as:

$$
\frac{\partial^{2} T(z)}{\partial z^{2}}-\frac{Q_{v} \rho_{0} c_{0}}{K} \frac{d T(z)}{d z}=0
$$

When $z=0$, the $T_{z}=T_{0}$, and when $z \rightarrow \infty$, the $T_{z}$ would be constant, then $T_{z}=T_{L}$. And the solution of equation (2) can be expressed as (Anibas et al., 2011):

$$
Q_{v}=\left|\frac{K}{\rho_{0} c_{0}} \ln \frac{T(z)-T_{L}}{T_{0}-T_{L}}\right|
$$

where $Q_{v}$ is the water exchange at $\mathrm{z}$ depth, $T_{0}$ is the measurement of the temperature at the upper sediments; $\rho_{0} c_{0}$ is the volumetric heat capacity of the fluid; and $T_{L}$ is the constant groundwater temperature.

\subsection{Determination of water exchange} patterns

The water exchange pattern is determined using the conceptual diagram (Figure 3), and in this method the water-thermal transport is based on the steady state (Anibas et al., 2011). In present study, the upper sediment temperature varies with the testing sites, and the lower temperature is groundwater temperature which is constant. When the groundwater discharges the surface water, the heat would transport from deep depth to the interface between surface water and sediment, showing the upward flux. When the surface water recharges the groundwater, the heat would transport into the sediment, displaying the downward flux.

\section{Results}

\subsection{Temperature profiles and water exchange patterns}

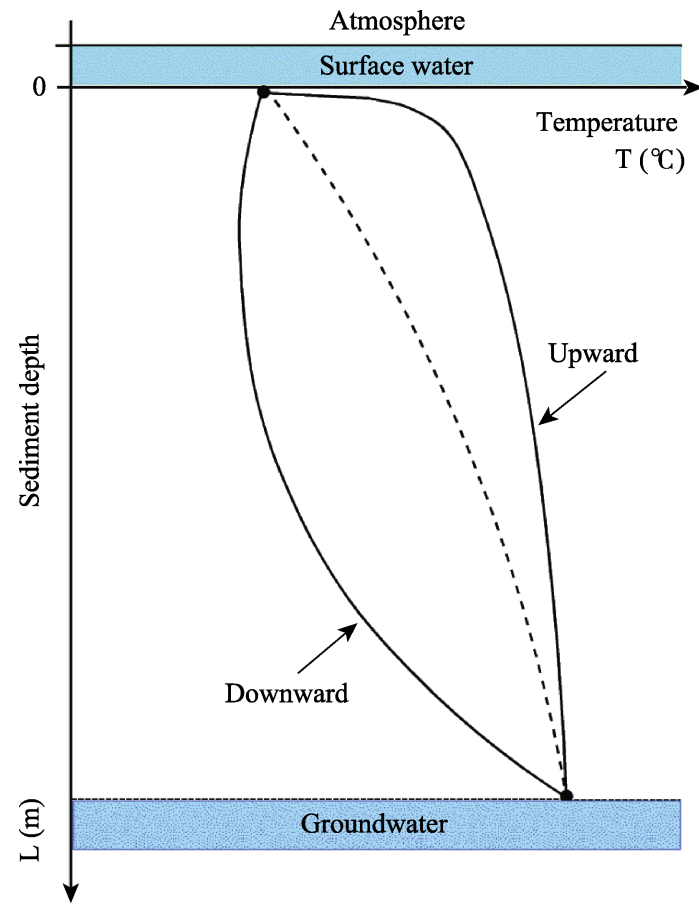

Figure 3 Conceptual diagram using vertical temperature distributional profile to determine hyporheic water exchange pattern (modified from the study by Anibas et al. (2011)

Figure 4 summaries temperature profiles and water exchange patterns at the ten testing sites (points) within the SWP. The maximum of the sediment temperature is $8.7^{\circ} \mathrm{C}$ in the $0.8 \mathrm{~m}$ depth at point 3 ; the minimum is $3.3^{\circ} \mathrm{C}$ in the upper layer at the point 4 . The average temperature of the upper layer and the deepest layer ranges from 5 to $8.3^{\circ} \mathrm{C}$. There exists a strong upward flow from the groundwater to surface water at the points $1-3$, especially at the point 1 . Inversely, there exists a downward flow from the surface water to groundwater at points 5-9. However, at points 4 and 10, the water exchange pattern shows two patterns, 
meaning that water exchange patterns differ in depth.
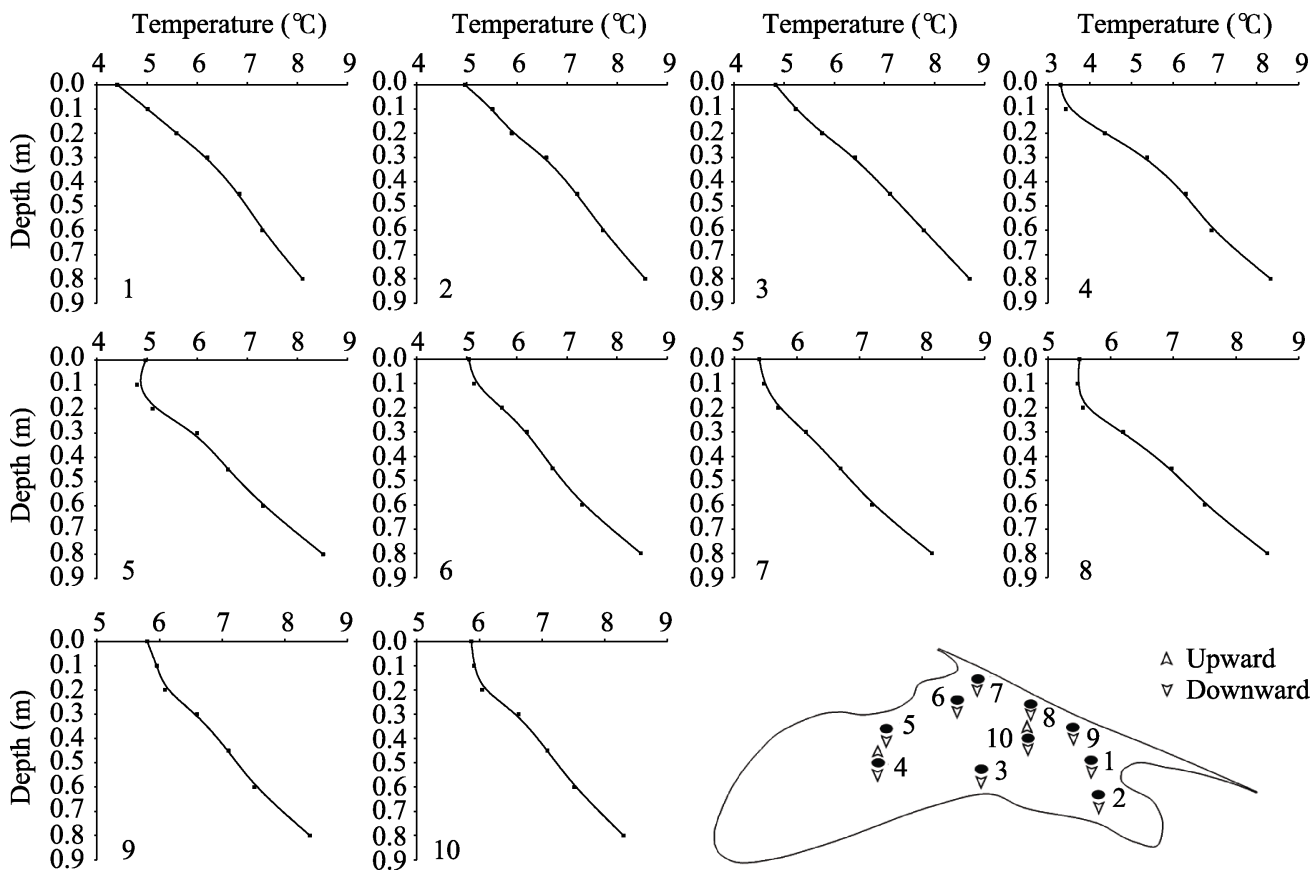

Figure 4 The analysis of the temperature of the sediments and schematic diagram of hyporheic water exchange patterns in the slack water pool

The belt (e.g., the points 7-9) connects the main river channel and the body of SWP (Figure $2 \mathrm{~b}$ ). The temperature-depth profiles would represent the interactions between groundwater and stream water, which oscilloscope apparently very flexible in certain depth (about at $0.2 \mathrm{~m}$ ), and the temperature tends to the violation of the thermal steady state assumption in this range (Conant, 2004).

\subsection{Hyporheic water exchange in the SWP}

Figure 5a shows the water exchange magnitude in the SWP. The water exchange can be divided into three categories: high fluxes (including points 1, 2, 3 and 4), moderate fluxes (including points 5 and 6) and low fluxes (including 7, 8, 9 and 10).

There exists a significant relationship between surface water temperatures and the water exchange magnitudes (Figure $5 b$ ), indicated by $\mathrm{R}^{2}=0.78$. The maximum water exchange is about $35.7 \mathrm{~mm} / \mathrm{d}$ occurring at point 4 , where the minimum surface water temperature of 3.7 ${ }^{\circ} \mathrm{C}$ is observed. The maximum surface water temperature is $5.8^{\circ} \mathrm{C}$ at point 6 where the water exchange is $14.0 \mathrm{~mm} / \mathrm{d}$.

\subsection{Spatial pattern of $\mathrm{HZ}$ water exchange within the SWP}

Figure 6 shows the spatial pattern of water exchange within the SWP. There exists significant spatial pattern. Firstly, the water exchange close to the opposing flow-direction bank (points 1,2 and 3) is stronger, and the mean of water exchange magnitude is $34.76 \mathrm{~mm} / \mathrm{d}$, about 1.6 times of the mean of $21.93 \mathrm{~mm} / \mathrm{d}$ that close to the flow-direction bank (points 5,6 and 7). Secondly, the water exchange becomes stronger when the location within the SWP is 
farther from the main channel.

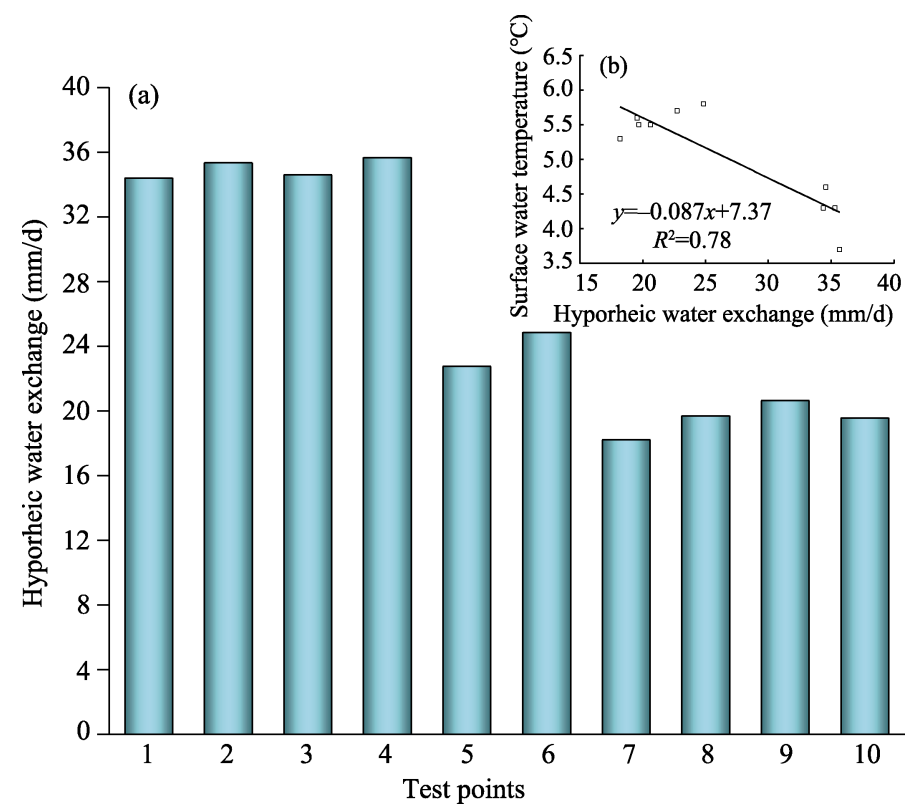

Figure 5 The hyporheic water exchange magnitude (a) and its relationship between surface water temperatures in different positions (b)

\section{Discussion}

\subsection{Temperature variations}

Various elements can affect the temperature gradient changes due to the structural features of SWP, the main dynamics including spatiality of the runoff, hydraulic conduc-

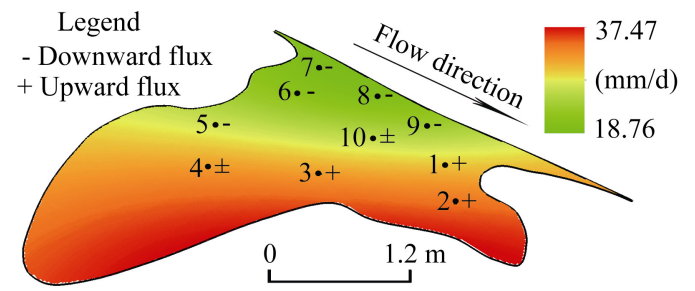

Figure 6 Spatial pattern of hyporheic water exchange within the slack water pool tivity, and fluctuation from surface flow and wind. As an important characteristic link to the runoff, the spatial rainfall variability has impacts on the hydrogeological response (Sapriza-Azuri et al., 2015), and features directly affect the evolution of groundwater heads, and thereby influencing the surface-subsurface water exchanges (Trauth and Fleckenstein, 2017). In some regions, the intense precipitation over arid areas in a long time is associated with divergent flows (Kumar et al., 2015), when the flow merges in a catchment in a short time, and the water body in the micro-topography structures may be subject to intensive variations than normality. Meanwhile, the hydraulic gradient along the sediment-water interface is highly sensitive to the spatial structure of bedforms (Min et al., 2013; Chen et al., 2015), when the interface is influenced by the surface water flow, there would appear the fluctuation of pressure gradient, turbulent water flow from main river channel and the withdraw water into the river channel, which from the SWP edge would form a merging flow, this process would create the convection for the surface water. Furthermore, changes of minerals and grain sizes attributes in natural sediments (Rau et al., 2014) are combined with fluctuation from flow and wind, the heat rearrangement will take place within the SWP (Peralta-Maraver et al., 2018). 


\subsection{Drivers of water exchange pattern within the slack water pool}

Two factors are potential contributors to exchange pattern in SWP: including that (1) the location in this system, and (2) the water status. There exists a series of the bends between the SWP and river bank. The water path in the subsurface can be more complicated than one direction river channel and have more direction changes, the groundwater discharge would be disturbed by this flow path. The meander bends of the stream can generate the near-stream flow paths according to their direction for the local groundwater network (Larkin and Sharp, 1992; Wroblicky et al., 1998). The location in the SWP has various meanders, hyporheic water exchange has the response to the flow variations resulted in topographic structures. For instance, some studies have revealed that the hydraulic properties of stream flow can induce the changing water exchange in the streambed and river banks (Malard et al., 2002; Tonina and Buffington, 2007; Zhang et al., 2016). The distribution of uniform groundwater flow leads to the dissolved substance variations in liquid phase and has relevance with the permeability (Koch and Nowak, 2015), so water exchange has feedback on the varieties of hydrological exchanges in river corridor.

Locations in the SWP influence the distribution of energy and create the changes of the properties in the sediment such as bubbles. Bubbles within porous media have an essential role in groundwater flow into the saturated zone (Ramirez et al., 2015). Conversely, in gaining river systems, the storm events can cause the changes of catchment size and shape, and form a temporary reversal of vertical hydraulic gradients, leading to surface water infiltration into the subsurface (Dudley-Southern and Binley, 2015), and then influence the groundwater discharge (Malcolm et al., 2006; Boano et al., 2008). However, the upwelling groundwater can block surface water infiltration (Gerecht et al., 2011), potentially reducing the nutrient attenuation capacity of the hyporheic zone (Rivett et al., 2008). The incomplete knowledge of aquifer properties under the surface water at few depths creates a problematic uncertainty (Josset et al., 2015). The groundwater table mainly influences the water body and the water flow from the river in HZ (Trauth and Fleckenstein, 2017). In the area close to the river bank, those two mechanisms would be separated by higher groundwater table generated from riparian. Another one, the flow velocity is relatively low and water status within the SWP is relatively steady. The water exchange in this condition is different from the flow individually controlled by main river channel or groundwater discharge. The water exchange gradient would be varied when the river water infiltrates this sediment system. In a period, the groundwater level is correlated to water volume and river recharge into this system. The flow of slightly compressible fluids through fractured rocks is of fundamental importance to groundwater (Kuhlman et al., 2015). The surface flow can propagate into the SWP; this may be associated with the system state and lateral sediments (Nazemi and Wheater, 2014; Wang et al., 2017).

Heterogeneity of the sediment and slope changes from the bank to the river channel would also lead to the spatial patterns of water exchange within the SWP. The complex sediment structure influences the water exchange greater than the homogeneous sediment structure (Conant Jr et al., 2004), the sediments with fine-sort particles are relatively uniform media and tend to have a good path. The sediment structure in the SWP is more heterogeneous than uniform riverbed, the sediment structure characterized by uneven spatial 
distribution and can drive the $\mathrm{HZ}$ water exchange pattern changes (Bellin et al., 2015). In the SWP, the element influencing the HZ water exchange is more variable than smooth river bank line. For instance, the vertical hydraulic conductivity is distributed spatially in different parts like in meandering riverbed (Jiang et al., 2015; Pozdniakov et al., 2016), the pore-scale processes and structures are the mechanisms leading to sediment structure changes (Schmeeckle et al., 2007). And from the distance the SWP to the main river channel, the HZ water exchange is strong near the river bank. This may be related to the pressure from the bank and the groundwater to the SWP. However, the mean particle friction does not vary systematically with bed slope in steep channels (Prancevic and Lamb, 2015). In the SWP, there exists a steep area with the rise of the river bank and forms a slop increase, the streambed sediments and the groundwater path would response to the slop within the SWP, pore in this streambed sediment subject to increase due to the decline of the water saturation degree. The water exchange process is characterized by complex spatial dynamics under the attributes of geomorphologic units (Boano et al., 2010; Doble et al., 2012), the characteristics of the sediment property and slope relative to the river bank are important for the spatiality of the HZ water exchange in the SWP (Gualtieri et al., 2017; Ianniruberto et al., 2017).

\section{Implications}

The challenge remaining for future work is to determine the extent to which pattern of the SWP can be most influenced by the water exchange and how to estimate this degree. Despite these compelling properties exhibited by SWP, several limitations may be attributed to the application of the one-dimensional equation. This method is more focused on the vertical exchange in this area, and the consideration for water exchange from the lateral zone is insufficient.

\section{Conclusions}

This study investigates the hyporheic water exchange in slack water pool using the thermal method. We found that hyporheic water exchange is mainly controlled by the location and water status in a slack water pool. There exists substantial spatial pattern on water exchange within slack water pool. River recharge dominates the water exchange in the area close to the flow-direction bank; while groundwater discharge dominates the water exchange in the area close to the opposing flow-direction bank. Furthermore, the exchange becomes stronger with the location farther from the main river channel.

The thermal approach provides an efficient method to determine the water exchange pattern, calculate the water exchange magnitude, and obtain the spatial information in some more complex geological structures. But for a slack water pool, there are some uncertainties due to the river flow and other artificial constructions such as a dam. The impact of constructions along the stream and the scale of slack water pool for the river channel have a very different influence on the results. In the future studies, care must be taken when comparing the data from the new conditions to probe more information driving the hyporheic water exchange.

\section{Acknowledgements}

We thank Guotao Zhang, Weiwei Jiang, Yuanyuan Wang, Ming Wen, Shaofeng Xu, and 
other members for assistance in fieldwork. In particular, we are grateful to the editor and two anonymous reviewers for providing numerous comments and suggestions, which helped improve this manuscript.

\section{References}

Anibas C, Buis K, Verhoeven R et al., 2011. A simple thermal mapping method for seasonal spatial patterns of groundwater-surface water interaction. Journal of Hydrology, 397(1): 93-104.

Anibas C, Fleckenstein J H, Volze N et al., 2009. Transient or steady-state? Using vertical temperature profiles to quantify groundwater-surface water exchange. Hydrological Processes, 23(15): 2165-2177.

Baxter C, Hauer F R, Woessner W W, 2003. Measuring groundwater-stream water exchange: New techniques for installing minipiezometers and estimating hydraulic conductivity. Transactions of the American Fisheries Society, 132(3): 493-502.

Bellin A, Tonina D, Marzadri A, 2015. Breakthrough curve moments scaling in hyporheic exchange. Water Resources Research, 51(2): 1112-1126.

Boano F, Camporeale C, Revelli R et al., 2006. Sinuosity-driven hyporheic exchange in meandering rivers. Geophysical Research Letters, 33(18): L18406.

Boano F, Revelli R, Ridolfi L, 2008. Reduction of the hyporheic zone volume due to the stream-aquifer interaction. Geophysical Research Letters, 35(9): L09401.

Boano F, Revelli R, Ridolfi L, 2010. Effect of streamflow stochasticity on bedform-driven hyporheic exchange. Advances in Water Resources, 33(11): 1367-1374.

Boulton A J, Datry T, Kasahara T et al., 2010. Ecology and management of the hyporheic zone: Stream-groundwater interactions of running waters and their floodplains. Journal of the North American Benthological Society, 29(1): 26-40.

Cardenas M B, Wilson J, Zlotnik V A, 2004. Impact of heterogeneity, bed forms, and stream curvature on subchannel hyporheic exchange. Water Resources Research, 40(8): W08307.

Caruso A, Ridolfi L, Boano F, 2016. Impact of watershed topography on hyporheic exchange. Advances in Water Resources, 94: 400-411.

Chen X, Dong W, Ou G et al., 2013. Gaining and losing stream reaches have opposite hydraulic conductivity distribution patterns. Hydrology and Earth System Sciences, 17(7): 2569-2579.

Chen X B, Cardenas M B, Chen L, 2015. Three-dimensional versus two-dimensional bed form-induced hyporheic exchange. Water Resources Research, 51(4): 2923-2936.

Cheng D H, Chen X H, Huo A D et al., 2013. Influence of bedding orientation on the anisotropy of hydraulic conductivity in a well-sorted fluvial sediment. International Journal of Sediment Research, 28(1): 118-125.

Conant B, 2004. Delineating and quantifying ground water discharge zones using streambed temperatures. Groundwater, 42(2): 243-257.

Conant Jr B, Cherry J A, Gillham R W, 2004. A PCE groundwater plume discharging to a river: Influence of the streambed and near-river zone on contaminant distributions. Journal of Contaminant Hydrology, 73(1): 249-279.

Darracq A, Destouni G, Persson K et al., 2009. Quantification of advective solute travel times and mass transport through hydrological catchments. Environmental Fluid Mechanics, 10(1/2): 103-120.

Doble R, Brunner P, McCallum J et al., 2012. An analysis of river bank slope and unsaturated flow effects on bank storage. Groundwater, 50(1): 77-86.

Dochartaigh B, MacDonald A, Archer N et al., 2012. Groundwater-surface water interaction in an upland hillslope-floodplain environment, Eddleston, Scotland, BHS 11th National Symposium, Hydrology for a Changing World, Dundee, Scotland, pp. 2012.

Dudley-Southern M, Binley A, 2015. Temporal responses of groundwater-surface water exchange to successive storm events. Water Resources Research, 51(2): 1112-1126.

Dunster K, 2011. Dictionary of Natural Resource Management. UBC Press.

Fischer H, Kloep F, Wilzcek S et al., 2005. A river's liver-microbial processes within the hyporheic zone of a large lowland river. Biogeochemistry, 76(2): 349-371. 
Fox A, Boano F, Arnon S, 2014. Impact of losing and gaining streamflow conditions on hyporheic exchange fluxes induced by dune-shaped bed forms. Water Resources Research, 50(3): 1895-1907.

Frei S, Lischeid G, Fleckenstein J H, 2010. Effects of micro-topography on surface-subsurface exchange and runoff generation in a virtual riparian wetland: A modeling study. Advances in Water Resources, 33(11): $1388-1401$.

Gerecht K E, Cardenas M B, Guswa A J et al., 2011. Dynamics of hyporheic flow and heat transport across a bed-to-bank continuum in a large regulated river. Water Resources Research, 47: W03524.

Gualtieri C, Filizola Jr N, Oliveira M et al., 2017. A field study of the confluence between Negro and Solimões rivers. Part 1: Hydrodynamics and sediment transport. Comptes Rendus Geoscience, 350(1/2): 31-42.

Ianniruberto M, Trevethan M, Pinheiro A et al., 2017. A field study of the confluence between Negro and Solimões rivers. Part 2: Bed morphology and stratigraphy. Comptes Rendus Geoscience, 350(1/2): 43-54.

Irvine D J, Lautz L K, Briggs M A et al., 2015. Experimental evaluation of the applicability of phase, amplitude, and combined methods to determine water flux and thermal diffusivity from temperature time series using VFLUX 2. Journal of Hydrology, 531: 728-737.

Isiorho S A, Meyer J H, 1999. The effects of bag type and meter size on seepage meter measurements. Groundwater, 37(3): 411-413.

Jiang W, Song J, Zhang J et al., 2015. Spatial variability of streambed vertical hydraulic conductivity and its relation to distinctive stream morphologies in the Beiluo River, Shaanxi Province, China. Hydrogeology Journal, 23(7): 1617-1626.

Josset L, Ginsbourger D, Lunati I, 2015. Functional error modeling for uncertainty quantification in hydrogeology. Water Resources Research, 51(2): 1050-1068.

Kalbus E, Reinstorf F, Schirmer M, 2006. Measuring methods for groundwater-surface water interactions: A review. Hydrology and Earth System Sciences, 10(6): 873-887.

Kasahara T, Wondzell S M, 2003. Geomorphic controls on hyporheic exchange flow in mountain streams. Water Resources Research, 39(1): SBH 3-1-SBH 3-14.

Koch J, Nowak W, 2015. Predicting DNAPL mass discharge and contaminated site longevity probabilities: Conceptual model and high-resolution stochastic simulation. Water Resources Research, 51: 806-831.

Korbel K L, Hose G C, 2015. Habitat, water quality, seasonality, or site? Identifying environmental correlates of the distribution of groundwater biota. Freshwater Science, 34(1): 329-343.

Kuhlman KL, Malama B, Heath J E, 2015. Multiporosity flow in fractured low-permeability rocks. Water Resources Research, 51(2): 848-860.

Kumar K N, Entekhabi D, Molini A, 2015. Hydrological extremes in hyperarid regions: A diagnostic characterization of intense precipitation over the Central Arabian Peninsula. Journal of Geophysical Research: Atmospheres, 120: 1637-1650.

Larkin R G, Sharp J M, 1992. On the relationship between river-basin geomorphology, aquifer hydraulics, and ground-water flow direction in alluvial aquifers. Geological Society of America Bulletin, 104(12): 1608-1620.

Lautz L K, Siegel D I, 2006. Modeling surface and ground water mixing in the hyporheic zone using MODFLOW and MT3D. Advances in Water Resources, 29(11): 1618-1633.

Li Q, Song J X, Wei A et al., 2013. Changes in major factors affecting the ecosystem health of the Weihe River in Shaanxi Province, China. Frontiers of Environmental Science \& Engineering, 7(6): 875-885.

Malard F, Tockner K, Dole-Olivier M J et al., 2002. A landscape perspective of surface-subsurface hydrological exchanges in river corridors. Freshwater Biology, 47(4): 621-640.

Malcolm I A, Soulsby C, Youngson A F, 2006. High-frequency logging technologies reveal state-dependent hyporheic process dynamics: Implications for hydroecological studies. Hydrological Processes, 20(3): 615-622.

Marzadri A, Tonina D, McKean J A et al., 2014. Multi-scale streambed topographic and discharge effects on hyporheic exchange at the stream network scale in confined streams. Journal of Hydrology, 519: 1997-2011.

Mendoza-Lera C, Datry T, 2017. Relating hydraulic conductivity and hyporheic zone biogeochemical processing to conserve and restore river ecosystem services. Science of the Total Environment, 579: 1815-1821.

Min L L, Yu J J, Liu C M et al., 2013. The spatial variability of streambed vertical hydraulic conductivity in an intermittent river, northwestern China. Environmental Earth Sciences, 69(3): 873-883.

Naiman R J, Latterell J J, 2005. Principles for linking fish habitat to fisheries management and conservation. Journal of Fish Biology, 67: 166-185. 
Nazemi A, Wheater H S, 2014. How can the uncertainty in the natural inflow regime propagate into the assessment of water resource systems? Advances in Water Resources, 63: 131-142.

Peralta-Maraver I, Reiss J, Robertson A L, 2018. Interplay of hydrology, community ecology and pollutant attenuation in the hyporheic zone. Science of the Total Environment, 610/611: 267-275.

Pozdniakov S P, Wang P, Lekhov M V, 2016. A semi-analytical generalized Hvorslev formula for estimating riverbed hydraulic conductivity with an open-ended standpipe permeameter. Journal of Hydrology, 540: 736-743.

Prancevic J P, Lamb M P, 2015. Particle friction angles in steep mountain channels. Journal of Geophysical Research: Earth Surface, 120(2): 242-259.

Ramirez J A, Baird A J, Coulthard T J et al., 2015. Testing a simple model of gas bubble dynamics in porous media. Water Resources Research, 51(2): 1036-1049.

Rau G C, Andersen M S, McCallum A M et al., 2014. Heat as a tracer to quantify water flow in near-surface sediments. Earth-Science Reviews, 129: 40-58.

Rivett M O, Buss S R, Morgan P et al., 2008. Nitrate attenuation in groundwater: A review of biogeochemical controlling processes. Water Research, 42(16): 4215-4232.

Sapriza-Azuri G, Jódar J, Navarro V et al., 2015. Impacts of rainfall spatial variability on hydrogeological response. Water Resources Research, 51(2): 1112-1126.

Schmeeckle M W, Nelson J M, Shreve R L, 2007. Forces on stationary particles in near-bed turbulent flows. Journal of Geophysical Research, 112(F2): F02003.

Schmidt C, Conant Jr B, Bayer-Raich M et al., 2007. Evaluation and field-scale application of an analytical method to quantify groundwater discharge using mapped streambed temperatures. Journal of Hydrology, 347(3): 292-307.

Somogyvári M, Bayer P, Brauchler R, 2016. Travel-time-based thermal tracer tomography. Hydrology and Earth System Sciences, 20(5): 1885-1901.

Song J X, Zhang G T, Wang W Z et al., 2017. Variability in the vertical hyporheic water exchange effected by hydraulic conductivity and river morphology at a natural confluent meander bend. Hydrological Processes, 31(19): 3407-3420.

Stegen J C, Johnson T, Fredrickson J K et al., 2018. Influences of organic carbon speciation on hyporheic corridor biogeochemistry and microbial ecology. Nat. Commun., 9(1): 585.

Storey R G, Howard K W F, Williams D D, 2003. Factors controlling riffle-scale hyporheic exchange flows and their seasonal changes in a gaining stream: A three-dimensional groundwater flow model. Water Resources Research, 39(2): 1034.

Stubbington R, 2012. The hyporheic zone as an invertebrate refuge: A review of variability in space, time, taxa and behaviour. Marine and Freshwater Research, 63(4): 293-311.

Suzuki S, 1960. Percolation measurements based on heat flow through soil with special reference to paddy fields. Journal of Geophysical Research, 65(9): 2883-2885.

Tonina D, Buffington J M, 2007. Hyporheic exchange in gravel bed rivers with pool-riffle morphology: Laboratory experiments and three-dimensional modeling. Water Resources Research, 43(1): W01421.

Trauth N, Fleckenstein J H, 2017. Single discharge events increase reactive efficiency of the hyporheic zone. Water Resources Research, 53(1): 779-798.

Vogt T, Schirmer M, Cirpka O A, 2012. Investigating riparian groundwater flow close to a losing river using diurnal temperature oscillations at high vertical resolution. Hydrology and Earth System Sciences, 16(2): $473-487$.

Wang P, Pozdniakov S P, Vasilevskiy P Y, 2017. Estimating groundwater-ephemeral stream exchange in hyper-arid environments: Field experiments and numerical simulations. Journal of Hydrology, 555: 68-79.

Wang W Z, Song J X, Zhang G T et al., 2018. The influence of hyporheic upwelling fluxes on inorganic nitrogen concentrations in the pore water of the Weihe River. Ecological Engineering, 112: 105-115.

Westhoff M C, Gooseff M N, Bogaard T A et al., 2011. Quantifying hyporheic exchange at high spatial resolution using natural temperature variations along a first-order stream. Water Resources Research, 47(10): W10508.

Wroblicky G J, Campana M E, Valett H M et al., 1998. Seasonal variation in surface-subsurface water exchange and lateral hyporheic area of two stream-aquifer systems. Water Resources Research, 34(3): 317-328.

Zhang G T, Song J X, Wen M et al., 2017. Effect of bank curvatures on hyporheic water exchange at meter scale. Hydrology Research, 48(2): 355-369. 